\title{
How and Why Fascism and Nazism BeCAME THE “Right”
}

\author{
Allen Gindler
}

\begin{abstract}
The Left has been represented by various currents that have historically been very aggressive toward each other because they used different tactics and strategies to achieve socialism. Like many intellectuals, revolutionary leftists did not get along with each other very often. Since the inception of Marxism, which is the doctrine of communism - an extreme and distinctive flavor of socialism - the Far Left has portrayed adherents of less revolutionary ideologies as enemies of the working people. The followers of evolutionary socialism-the Social Democrats-were accused by the Communists of betraying the proletariat. Non-Marxist currents of socialism, such as fascism and National Socialism, were excluded from the socialist camp and put on the right wing by Marxist-Leninist propaganda. Stalinist political science became a benchmark that distinguished between the genuine Left and the Right. This article shows the origin and historical background of the artificial shift of fascism and National Socialism to the right side of the political spectrum.
\end{abstract}

$\mathrm{T}$ he prevailing and already traditional point of view, reflected both in school textbooks and in popular culture, is the attribution of fascism and Nazism to the ultraright of the political spectrum. However, any tradition has its origin. This article posits that the convention of affiliating fascism and National Socialism with the right wing originated during the acute ideological war between Marxist and non-Marxist currents of socialism in the first

\footnotetext{
Allen Gindler (agindler@cyberrex.com) is a scholar from the former USSR specializing in political economy, econometrics, and industrial engineering. He taught economic cybernetics, standard data systems, and computer-aided work design in the Khmelnytskyi National University, Ukraine. He is currently a private consultant to IT industry on database administration and cryptography.
} 
half of the twentieth century. That war had several hot outbreaks where Fascists and Nazis eliminated evolutionary socialists and communists in their corresponding countries and abroad, whereas Bolsheviks did the same to other fellow socialists. The primary battle was fought during World War II, where the Soviets had the upper hand over Italian Fascists and Nazi Germany. As the victor in the bloody war, they rewrote and propagandized their version of history, cementing non-Marxian flavors of socialism on the right wing of the political spectrum.

Neither the Fascists nor the Nazis identified themselves with the class of entrepreneurs but positioned themselves primarily as pacifiers between labor and capital. Benito Mussolini (1933), already the prime minister and head of the Fascist Party, declared that the twentieth century "will be a century of authority, a century of the Left, a century of fascism ... it may be expected that this will be the century of collectivism, and hence the century of the State." The historian Michael T. Florinsky (1938), who was one of the earliest researchers of fascism and National Socialism and a direct witness of the formation of these two regimes, presented a clear picture of the socialist transformations in Italy and Germany, respectively. Another contemporary of Italian fascism, economist Fausto Pitigliani (1933), took upon himself the task of familiarizing non-Italian readers with the principles of the corporative state. He acknowledged a significant socialist feature of the corporate structure of the state:

The function of private enterprise is assessed from the standpoint of public interest, and hence an owner or director of the business undertaking is responsible before the State for his production policy. Thus, the State reserves to itself the right to intervene and to take the place of the individual, should he misuse his rights. (Pitigliani 1933, x)

A prominent representative of the Austrian school of economics, Ludwig von Mises ([1949] 1998, 813) straightaway identified Italian fascism as a "rebaptized edition of guild socialism." Murray N. Rothbard (2009, 1273-74) concluded:

All forms of State planning of the whole economy are types of socialism, notwithstanding the philosophical or esthetic viewpoints of the various socialist camps and regardless whether they are referred to as "rightists" or "leftists." Socialism may be monarchical; it may be proletarian; it may equalize fortunes; it may increase inequality. Its essence is always the same: total coercive State dictation over the economy. 
Although both Fascists and Nazis self-identified their doctrines as belonging to the left wing and contemporaries observed an obvious socialist tilt in the socioeconomic structure of Italy and Germany, left-leaning intellectuals have vigorously opposed any suggestion that fascism and National Socialism were phenomena of the Left and had a wonderful affinity with the Soviet and other Communist regimes. Utter denial of the similarity between far-left and supposedly far-right systems has its own fascinating history and stormy dynamics. In order to trace all the vicissitudes of the political struggle within the European left, it is necessary to scrutinize episodes of the most turbulence, which are here presented in relation to the following events of great importance: World War I, the Bolshevik revolution, the ascent of fascism in Italy, the rise of Nazism in Germany, the Spanish Civil War, World War II, and the Cold War. These events shaped the general provisions of various leftist currents, crystallizing their convictions on vital issues of the socioeconomic structure of society.

\section{BEFORE THE GREAT WAR}

Before World War I, the left-wing movement enjoyed unparalleled development worldwide, especially in Europe. Perhaps the Left became the most literature-productive political movement in the second half of the nineteenth century and the beginning of the twentieth century. They had generated various ideas on how to improve human society. The Left appreciated the numerous revolutions, upheavals, strikes, sabotages, and protests that shook European countries during that period. These allowed them to come up with various visions for the end of capitalism. Leftists' political ideas differed on methods, tactics, and strategies but agreed on the common enemy-capitalism.

The second half of the nineteenth century was dominated by the socialist ideas advanced by Karl Marx and Friedrich Engels. Marxism was one of the most influential and revolutionary teachings. It seemed to be an unshakable and intransigent ideology, equipped with the so-called scientific political economy, materialist dialectics, and historical materialism. Marxism attempted to scrupulously explain the inner mechanism of human societies' advances and ways of attaining a bright future. This teaching brought hard-core revolutionaries together; however, it is erroneous to suggest that Marxism embraced all of socialism. 
Instead, Marxism is a particular and extreme current of socialism called communism. In other words, Marxism is undoubtedly leftist, but the Left is not entirely Marxist. Marxism did not invent socialist thought, which originated centuries earlier and is known by the collective name "utopian socialism." Marxism's founders initiated the communist camp and clearly distinguished themselves from contemporary socialists, whom they contemptuously called "so-called socialists."

Engels (1969, 81-97) identified three categories of socialists in the middle of nineteenth century: reactionary socialists, bourgeois socialists, and democratic socialists. The first category included adherents of feudal society who clearly saw all the evils of capitalism but wanted to cure society by restoring the old aristocracy's rule, the guild masters, and the small producers. Engels added them to the list of enemies of communists, as he understood that they wanted something that is utterly impossible-to reverse the history of societal evolution.

The bourgeois socialists intended to keep capitalism but improve it through comprehensive welfare reforms. Engels (1969, 81-79) emphasized that "[c]ommunists must unremittingly struggle against these bourgeois socialists because they work for the enemies of communists and protect the society which communists aim to overthrow."

According to Engels, the last group-democratic socialistsshared the majority of communists' political objectives but stopped short of accepting all the provisions of Marxist doctrine. They were satisfied with achieving goals within the framework of social democracy. Communists engaged in partnerships with democratic socialists and tried to convince them to embrace communist thought in its entirety.

Hence, socialism included many currents that were hostile to each other to a more considerable degree than to their common enemy - the democratic capitalist state. Marxists suggested quite radical ideas and treated their fellow socialists as politically illiterate dreamers equipped with neither strong theory nor a plan to reach a socialist paradise. Those who dared to cooperate with the bourgeoisie were uncompromisingly designated as enemies of the socialist idea. Nevertheless, even representatives of nonconformist socialist currents did not universally accept Marxism. 
Russian revolutionary anarchist Mikhail Bakunin heavily criticized Marx's provisions within the framework of the First International (1864-76). Namely, Bakunin (1873) disagreed with Marx on the proletarian dictatorship and the role of the state. He accused Marx of being an authoritarian and a proponent of statism:

\begin{abstract}
The theory of statism, as well as that of so-called "revolutionary dictatorship," is based on the idea that a "privileged elite," consisting of those scientists and "doctrinaire revolutionists" who believe that "theory is before social experience," should impose their preconceived scheme of social organization on the people. The dictatorial power of this learned minority is concealed by the fiction of a pseudo-representative government, which presumes to express the will of the people.
\end{abstract}

There were further disagreements between Marx and Bakunin. ${ }^{1}$ Bakunin's critiques did not influence Marx whatsoever; irreconcilable differences resulted in a schism between these two revolutionary movements-Marxism and anarchism. Shortly after that, in 1872, the First International was split, and both branches dissolved several years later.

The lesson to be learned and remembered is that left-wing intellectual circles were vibrant yet at the same time hostile environments. Despite the fact that the Left has only one common enemy-capitalism - intractable contradictions in the tactics and strategies of its overthrow made them implacable adversaries. Even though the bourgeoisie was the Left's openly proclaimed enemy, they were treated less harshly than opponents from their leftist circles, who were treated like vile traitors. History showed that as soon as one of the left-wing parties gained real power, it immediately persecuted its fellow socialists from other factions.

Revolutionaries were very impatient people; they wanted the socialist revolution to happen during their lifetime. As nothing of the sort had succeeded by the end of the nineteenth century, revolutionaries became puzzled and asked themselves whether Marx's theory adequately reflected historical processes.

On the academic front, the prominent economists of the time, representing the Austrian economic school, had pointed out

\footnotetext{
${ }^{1}$ Bakunin suggested that secret revolutionary societies become hotbeds of the revolutionary uprising, whereas Marx flatly rejected this proposition. He and Marx also contested the role of the peasants in a revolutionary movement. Bakunin argued that they might play a leading role, but Marx insisted that the proletariat should be designated as the sole agent of change.
} 
profound contradictions in Marxian economic theory. Eugen von Böhm-Bawerk repudiated the fundamental provisions of Marxian economics in his dedicated work Karl Marx and the Close of His System (Sweezy 1949), written in 1896. He showed that commodities were not exchanged in proportion to the amount of labor incorporated in them, as Marx thought. This fact alone invalidated Marxian "laws of value and surplus-value," which meant that subsequent theoretical implications were gravely jeopardized as well.

Furthermore, liberal democratic countries had not been developing according to the Marxian doctrine, either. The Marxian dichotomous model of modern capitalist society, consisting of just two opposing classes-proletariat and bourgeoisie-did not correspond to reality. Marx overlooked the middle class's growth trend, which had become the dominant stratum of society in industrialized countries. Besides, the division of the nation into classes corresponding to the factors of production makes sense only in the Marxist framework and does not have any value outside his theory (Mises 1951, 342-69).

In the 1890s, Marxism entered a period of crisis that was characterized by numerous efforts by the Left to improve Marx's teachings. The significant revision of Marxism took place within the narrow circle of its leading intellectuals, which included members of the Fabian Society and German socialist Eduard Bernstein, a personal friend and companion of Friedrich Engels. Bernstein considered himself a disciple of Marx and Engels and thought that it was his duty not to "everlastingly repeat the words of their masters"; instead, he insisted that "the further development and elaboration of the Marxist doctrine must begin with a criticism of it" (Bernstein 1907).

Bernstein pointed out that the modern capitalist society was continually improving the population's well-being and that as a result the class struggle would assume diminished importance. He criticized Marx's argument regarding concentration and centralization of production and wealth, stating that small and mediumsized businesses are not disappearing but rather flourishing along with large industries. He argued that the quantitative and qualitative characteristics of the proletariat changed and did not correspond to the picture which Marx observed in mid-nineteenthcentury Europe. Given the growing prosperity and diminishing class antagonism of the modern capitalist economy, Bernstein 
inferred that elements of the social superstructure (state, culture, ethics, art) were significant forces that influence an economic basis and together would work out a resulting vector of the historical process. Bernstein envisioned an evolution in societal ethics that would develop conditions in which it would be morally inappropriate for entrepreneurs to continue the unjust exploitation of the proletariat. Socialism would be brought about by the humanity of the majority of people, who would adopt socially oriented laws.

Bernstein's "reformism" was not well accepted by his colleagues and companions within the Social Democratic Party of Germany (Sozialdemokratische Partei Deutschlands, SPD) or by socialists abroad. Contradictions with orthodox Marxism were vivid and irreconcilable, which resulted in the prolonged Bernstein-Kautsky intellectual debates, which began after Engels' death in 1895 and continued until 1905 and were observed with undying interest by a vast audience of European socialists.

Karl Kautsky countered Bernstein's propositions from the strictly orthodox Marxist position. He insisted on the continuing trend of centralization and concentration of capital, worsening capitalist crises, and the impossibility of political rapprochement between labor and capital. Formally, Bernstein lost a battle because the leaders of the German Social Democratic Party-August Bebel and Karl Liebknecht-had chosen Kautsky's position. Bernstein miraculously escaped expulsion from the party despite many calls for it.

However, Bernstein won in a broader sense after all, as most Western European socialist parties accepted Bernstein's doctrine of conformist "reformism" in their practices. They accepted the scenario in which capitalism would run for a long time and that the best thing to do would be to cooperate and peacefully debate issues in the democratic parliament and find every opportunity to inject a dose of socialism into the body of capitalism.

Meanwhile, the Marxist flag was raised by the revolutionaries in the Russian Empire. Right away, Vladimir Lenin declared that the Marxist movement was undergoing "revisionism from the right," and thus explicitly pushed reformists to the right wing of the Left. He accused them of the most awful wickedness-betrayal of the proletariats' primary interests by seeking cooperation with the bourgeoisie within the walls of parliaments. Lenin notably labeled reformists proponents of the petty bourgeoisie (Lenin 1973a, 29-39). 
Simultaneously, France and Italy's far left developed a revolutionary syndicalist movement that despised liberalism and social democracy. The proponents of revolutionary syndicalism revised Marx beyond recognition; there remained only one rational process: the class struggle. Georges Sorel ([1908] 2014) and his disciples rejected Marx's economy, historical materialism, and philosophy. Instead, they adopted a theory of myths that would forge the will to revolution. The original myth that they worked on was that of the general strike. It was considered to be a united and organizing motivating force of the revolution, and violence became its instrument. Revolutionary syndicalists belong to a nonconformist movement dreaming of a revolution that will dismantle a democratic state by the force of proletarian violence, contrary to the evolutionary changes favored by social democracy. They preached the "new school" of socialism, which was antiMarxist, antimaterialist, and antipositivist.

Some revolutionary syndicalists rejected Marxian internationalism and the proletariat as a single agent of the socialist revolution. They adopted a doctrine of political nationalismusually in the form of anti-Semitism-that added a national syndicalist flavor to the socialist movement. They saw the patriotic and revolutionary elements of the whole nation as agents of the future social revolution. National syndicalism deviated from the internationalist provision of Marxism, which found its further development during World War I.

By the beginning of World War I, the Left constituted a motley conglomerate of movements that often held utterly opposite ideas about the development of society. They argued vigorously with each other about which thoughts were correct in achieving socialism. The only common ground was an antagonistic attitude toward capitalism and the democratic state. The democratic government was an open enemy, while the conformist evolutionary path to socialism was often seen as a betrayal of socialist goals. Extreme-left revolutionaries branded those groups as having gone to the Right.

Nevertheless, the majority of European leftist parties adopted social democratic "reformism" and "opportunism." These parties constituted the mainstream of the Second International, which was formed in 1889. 


\section{THE GREAT WAR}

The Great War caused another decisive split among the socialist currents, which widened the gap between them. At that time, the main problem was the confrontation between nationalism and internationalism. In his Communist Manifesto of 1848, Marx declared that the proletariat has no country and must unite against the capitalists (Marx 1969, 98-137). Since then, Marxism has been strongly associated with internationalism, as well as with the theory of surplus value and historical materialism. Gindler (2019) gave vivid examples of the fact that the founders of Marxism were not internationalists but rather racists and xenophobes by modern standards. Marxism's internationalist feature was a forced measure because Marxist theory advocated for simultaneous socialist changes throughout the civilized world. Marx and Engels explained the universal character of the socialist revolution as being primarily due to the universal, i.e., international, nature of capitalism. Engels $(1969,81-97)$ elucidated:

By creating the world market, big industry has already brought all the peoples of the Earth, and especially the civilized peoples, into such close relation with one another that none is independent of what happens to the others.

Therefore, Engels acknowledged the truism that capital does not have borders and encourages an international division of labor and cooperation. So it was capitalism and the capitalists that were naturally international. The proletariat just followed their example in creating international institutions that represented labor, which was mostly local in Marx's time. Therefore, the proletarians' internationalism was not assured by an exceptional moral quality that opposed nationalism and bigotry and exhibited unconditional love for all people on earth. It was a necessary condition for the Marxist theory to be logically consistent. Nevertheless, Marxists incorporated the theme of internationalism into their ideology, which it continues to be part of to this day.

In reference to World War I, the question of internationalism was formulated as follows: Should the Left support their own country or not? The answer to this question shook the entire leftist movement, as numerous members of the European socialist parties supported a defense of the national states. That was another deviation from Marxist teachings. The grievances of orthodox Marxists finally 
reached a boiling point. Lenin (1974b, 35-41) summarized those objections as follows:

Advocacy of class collaboration; abandonment of the idea of a socialist revolution and revolutionary methods of struggle; adaptation to bourgeois nationalism; losing sight of the fact that the borderlines of nationality and country are historically transient; making a fetish of bourgeois legality; renunciation of the class viewpoint and the class struggle, for fear of repelling the "broad masses of the population" (meaning the petty bourgeoisie) - such, doubtlessly, are the ideological foundations of opportunism.

This question had redefined a political spectrum within the left-wing cluster. Lenin noted that "during the two odd years of the war, the international socialist and working-class movement in every country has evolved three trends" (Lenin 1974c, 93-106): the social chauvinists, the "Centre," and true internationalists.

Lenin designated social chauvinist socialists as "our class enemy." He claimed they had "gone over to the bourgeoisie." This group included members of social democratic parties as well as revolutionary syndicalists that had already formed a national syndicalist movement. At the same time, Lenin acknowledged that they made up most of the official leaders of the social democratic parties in all countries. The center opposed the split and favored unity in the workers' movement, including social chauvinists. The center was not good enough for the hard-core Marxists, either:

The crux of the matter is that the "Centre" is not convinced of the necessity for a revolution against one's own government; it does not preach revolution; it does not carry on a wholehearted revolutionary struggle; and in order to evade such a struggle it resorts to the tritest ultra-"Marxist"-sounding excuses. (Lenin 1974c, 93-106)

The third faction was characterized by its complete break with both social chauvinists and the center. It adhered to the revolutionary struggle against its own imperialist government and its own imperialist bourgeoisie. This faction tried to convert imperialistic war into a civil war against its own government. Marx did not consider or underestimated that national interests were much more vital than class interests, especially during a war. It was naïve, if not imprudent, to expect the citizens of one country that was faced with a military intervention to reach a peer class in another antagonist country and unite with it. However, the Bolsheviks of 
Russia and the Spartacus League in Germany demanded precisely such an attitude from other workers' movements.

Consequently, the difference between Marxism, social democracy, and social chauvinism became wider and more irresoluble. Such profound disagreements resulted in the dismantling of the Second International in 1916.

Therefore, the Great War differentiated the leftist cluster of the political spectrum into three parts: the minority of orthodox Marxists on the extreme left, the pacifist center, and social chauvinists on the right. It is worth emphasizing that this division occurred only within the Left's cluster of the entire political spectrum. These factions together constituted the leftist movement, regardless of the orthodox Marxists' negativity toward the center and the right-leaning currents.

It is clear that the revolutionary minority of the extreme left had brushed off the rest of the more numerous socialist currents as opportunists and treacherous entities, thus alien to the interests of the working class. As such, they were labeled agents of the petty bourgeoisie.

\section{BOLSHEVIK REVOLUTION}

On October 25, 1917, the Bolsheviks scored a crucial moral victory against other currents of the socialist movement by organizing and leading the "Great October Socialistic Revolution" in Russia. It was the first country in the world where the Left overturned capitalism. Marxism-Leninism became the first leftist philosophy that was institutionalized. They managed not only to take power but also to defend it in the ensuing bloody civil war. That victory pushed Bolsheviks to the forefront of the socialist movement.

The Bolsheviks portrayed themselves not only as leading theorists but also as skillful practitioners of Marx's teachings. Therefore, all their critiques of other factions of the socialist movements became not merely validated but also indisputable. In their own view, only the Bolsheviks and their followers in Europe were dedicated representatives and defenders of proletarian interests, and the rest were collaborators with the bourgeoisie.

The rift between the social chauvinists and Bolsheviks became even more extensive and the attitude toward them even harsher during the Russian Civil War and Entente intervention (October 
1917-October 1922). As many social chauvinists were Entente troops, they were forced to fight against the Red Army of the Bolsheviks. In the "Invitation to the First World Congress," Trotsky ([1973] 2003) specifically outlined his attitude toward the social chauvinists:

Towards the social chauvinists, who everywhere at critical moments come out in arms against the proletarian revolution, no other attitude but a ceaseless struggle is possible. As to the "Centre," the tactics of splitting away the revolutionary elements and ruthlessly criticizing and exposing the leaders.

Thus, the Bolsheviks actively strengthened the far-left flank of socialists and led an offensive against more numerous socialist factions. The Bolsheviks' propaganda firmly established MarxismLeninism as a valid and indisputable continuation of Marx's theory. They proudly occupied the far left wing of the political spectrum, shifting all others to the right. As for anarchists, the Bolsheviks looked down on them as a movement without a coherent historical development theory. The Bolsheviks intended to rule alone and did not hesitate to eliminate all other parties and factions that did not share their perspective. Thus, the representatives of other leftist parties and party groups-Mensheviks, Constitutional Democrats (Kadets), Socialist Revolutionaries (SR), anarchists were repressed, exiled, or executed in the course of the Bolsheviks' power grab.

The Bolsheviks physically eliminated ideological opposition in their country and sought to impose their perspective on the world labor movement. In 1919, the Bolsheviks created the Communist International, or Comintern, to teach other leftists how to prepare socialist revolutions and spread communism throughout the world. The Comintern posed the problem of internationalism versus nationalism as a marker used to denote which political philosophy was genuinely socialist and which was fraudulent from the point of view of communism.

\section{MARCH ON ROME}

The Bolsheviks' magnificence did not last for a long time from a historical perspective. In just five years, Fascists took power in Italy by utilizing completely different means. Their revolutionary path was not Marxist at all. There was no bloody coup d'état either; numerous violent acts and protests culminated in the grotesque 
March on Rome, after which Mussolini was appointed prime minister. He had not even formulated a coherent Fascist doctrine at that time but took as a basis the revolutionary ideas of syndicalists and national syndicalists. The core of his movement was composed of social chauvinists by Lenin's definition-veterans of the Great War. However, Mussolini managed to form a vast coalition around the Fascist movement. There were social chauvinists, centrists, and some extreme leftists - all three factions of the Italian left; he won the support of the middle class and received funding from the Entente and some capitalists.

The non-Marxist overturn of capitalism undermined the Bolsheviks' authority in understanding and leading historical processes. Marxist-Leninists started to erect philosophical defensive barriers. Their general stance toward the Fascist movement in the early twentieth century was as follows. If fascism were an authentic proletarian revolution, then the working class would completely expropriate the means of production and establish a dictatorship of the proletariat. If this did not happen, then the proletariats would continue to be exploited. As such, fascism had not ousted capitalism.

On the contrary, smart capitalists had employed a vanguard of petty bourgeoisie-Fascists-and successfully defended their power. Fascists were not self-sustained players but rather fooled "reformists" and "national syndicalists" that had betrayed the proletariat. They were leftists but picaresque leftists, those on the right side of the leftist clusters: various followers of social chauvinists and some centrists attached to them. As the petty bourgeoisie was not a distinct class, it could not keep power for a long time and was destined to give it up to either the proletariat or the bourgeoisie.

In 1922, Leon Trotsky weighed the possibility that the Mussolini regime could be overthrown "by the régime of the proletarian dictatorship." He advised Italian Communists "to begin to disintegrate the plebeian and especially the working-class sector of Fascist support and to fuse ever broader proletarian masses under the partial and general slogans of defense and offense" (Trotsky [1974] 2003).

Trotsky's desperate exhortation was in vain. Italian Communists were defeated in the fierce and bloody internecine struggle of the Left. There remained no other proletarian masses for the 
Communists to appeal to. The majority of the working class had joined the Fascist movement. Ultimately, the Fascists unified the Italian left, whether voluntarily or by eliminating the resistance. Fascists purged their opposition and created a one-party, one-tradeunion system, as the Bolsheviks did in Russia. Both non-Marxist and Marxist currents of socialism achieved dictatorial regimes. The only difference was that the Fascist regime stood in the position of nationalism, while Communists continued to claim their internationalist stance. As far as property rights were concerned, Fascists allowed private property de jure and the Bolsheviks partially restored market relations in the course of the New Economic Policy from 1922 to 1928. Nevertheless, Communists insisted that they were genuine leftists and that Fascists were the depraved flavor of socialism, manipulated by the bourgeoisie.

\section{THE POLICY OF SOCIAL FASCISM}

Throughout the late 1920s, Marxist-Leninists continued to blame both social democracy and Fascists for being the primary support of capitalism in the working class. They stubbornly insisted that social democracy and fascism were the two incarnations of bourgeoisie exploitation; the former was masked, and the latter was naked. Thus, European social democracy was even more devilish than open fascism, as Social Democrats tried to camouflage the movement's real objectives. In an article titled "Concerning the International Situation," published on September 20, 1924, Joseph Stalin wrote: "Social Democracy is objectively the moderate wing of fascism.... They are not antipodes; they are twins" (Stalin [1954a] 2008, 293-314).

Comintern began a political campaign of depicting all Social Democrats as social fascists. This rivalry was a continuation of a class war advocated by Lenin against "reformists" and "opportunists." Instead of cooperation with other working-class currents, Communists chose a path of confrontation. Stalin accused Western social democracy of "imbuing the workers with skepticism, with distrust in their own strength, with disbelief in the possibility of achieving victory over the bourgeoisie by force" (Stalin [1954b] 2008).

The main issue with Social Democrats was that they had a majority of working-class support; two important countries-Great Britain and Germany - already had Social Democrats in the government, 
and Mussolini ruled Italy. All of them were outgrowths of the nonMarxist theory of "reformism" and "revisionism." Communism was not only becoming a minority; their "scientific" method did not hold water very well. ${ }^{2}$ Besides, the Communist revolutions in Germany (1918-19), Hungary (1918-20), and China (1925-27) had failed. Marxists figured out that if the trend continued, Marxism would be marginalized even further; the influence of communism on the working-class movement would be reduced to zero.

It was a struggle for survival and relevance for the MarxistLeninists of the Soviet Union and Comintern. Furthermore, Stalin accepted the role of a leading Marxist theoretician after purging most of the independent-thinking "old" Bolsheviks. Quite unexpectedly, in 1927, he announced at the Fifteenth Congress of the Communist Party of the Soviet Union (Bolsheviks) that the period of "capitalist stabilization" had ended, and the next, the so-called third period, had begun. Stalin ([1954c] 2009) asserted:

Whereas a couple of years ago it was possible and necessary to speak of
the ebb of the revolutionary tide in Europe, today we have every ground
for asserting that Europe is entering a period of new revolutionary
upsurge; to say nothing of the colonies and dependent countries, where
the position of the imperialists is becoming more and more catastrophic.

That period was described as a time of intense turmoil in capitalist countries and their colonies that would result in a new imperialistic war. As a devoted Leninist, he envisioned that a new war would produce yet another revolutionary situation. Communists could seize an opportunity to organize a revolt and take power as the Bolsheviks had in Russia. The next step would be a dictatorship of the proletariat, and Marxists did not intend to share power with anyone, including social democratic parties. Their mode of operation was to rule alone (identical to fascism).

Thus, they preventatively laid a groundwork of extricating working-class masses from Social Democracy in anticipation of a future struggle. Comintern demanded that its national sections carry out attacks on other groups in workers' movements. Those attacks were not limited to pure polemics. Comintern suggested physical intimidation of noncommunists and urged the initiation of armed uprisings.

2 The Russian Revolution itself was a sort of falsification of Marxism as a science, because it occurred before the formation of a proletarian class of industrialized workers - as opposed to after. This contradicts Marx's own system of "scientific socialism." 
Comintern held that social democracy was the direct support of capitalism in the working class and the chief enemy of communism. All other trends in the working class (anarchism, anarcho-syndicalism, guild socialism, etc.) were, in essence, varieties of social democracy (Stalin 1954e). In 1930, Stalin proclaimed from the highest tribune during the Sixteenth Congress of the Communist Party of the Soviet Union (Bolsheviks) that Social Democrats were social fascists (Stalin [1955] 2000). As Draper (1969) pointed out, "The theory of social-fascism was a rationalization of Communist dictatorship in the guise of rationalizing everyone else into a variety of fascism."

In the fierce internecine war inside the leftist cluster, Communists attempted to fight everyone and everywhere. This fight consequently widened the gap between the left and the right flanks of the leftist conglomerate.

\section{THE RISE OF NATIONAL SOCIALISM}

After World War I, another trend of non-Marxist socialism arose in Germany, namely National Socialism. Whereas Italian fascism inherited the vast theoretical provisions of the syndicalists and further developed them by introducing corporatism and totalitarianism, the National Socialists of Germany introduced a social democracy program on steroids, with the inclusion of aggressively nationalistic, anti-Semitic, and racist positions.

Adolf Hitler's nationalism and racism significantly differed from the nationalism that the world was accustomed to at that time. Traditional nationalism found its expression in a keen sense of patriotism, loyalty to the country, shared language, culture, and history, and a desire for the country's own well-being. German National Socialism was based on biological determinism. Hitler endorsed a militant, offensive, and genocidal nationalist theory of the Aryan race's superiority over others.

In the beginning, Hitler's contemporaries did not take the Nazi theory seriously. In 1934, at the Seventeenth Party Congress, Stalin ([1954d] 2008) jokingly said:

It is well known that ancient Rome looked upon the ancestors of the present-day Germans and French in the same way as the representatives of the "superior race" now look upon the Slav races. It is well known that ancient Rome treated them as an "inferior race," as "barbarians," destined to live in eternal subordination to the "superior race," to "great 
Rome," and, between ourselves be it said, ancient Rome had some grounds for this, which cannot be said of the representatives of the "superior race" of today. (Thunderous applause.)

At the same congress, Stalin officially labeled fascism as a "bourgeois-nationalist trend." Stalin did not distinguish between Italian fascism and German National Socialism in front of congress delegates. He called German National Socialism "fascism," using the same ideological and propaganda clichés that the Bolsheviks had used earlier to refer to any noncommunist parties and movements, to some degree because of the similarities of the emerging totalitarian states and the parallels in Mussolini's and Hitler's vicious tactics toward the opposition. ${ }^{3}$ Of course, Stalin thought that the Bolsheviks' atrocities toward opponents were well justified.

As for the "bourgeois" substance of the economy, Stalin applied Marxist reasoning, pointing out that private property in Fascist and Nazi states was not socialized according to Marx's recipe. During an interview with Roy Howard, Stalin ([1978] 2008) explained:

The foundation of the [socialist] society is public property: state, i.e., national and co-operative, collective farm property. Neither Italian fascism nor German National "Socialism" has anything in common with such a society. Primarily, this is because the private ownership of the factories and works, of the land, the banks, transport, etc., has remained intact, and, therefore, capitalism remains in full force in Germany and Italy.

In fact, Italian Fascists and German National Socialists found even more hideous ways to socialize private property than Marxist's straightforward expropriation. Dejure, private property was allowed, but de facto, businesspeople were deprived of the free commodity market, labor market, and international money market; dissident thoughts and actions were corrected by Gestapo and similar state agencies. Mises $(1951,56)$ very persuasively pointed out that private property is a mere name in the totalitarian planned economy:

If the State takes the power of disposal from the owner piecemeal, by extending its influence over production; if its power to determine what direction production shall be is increased, then the owner is left at last with nothing except the empty name of ownership, and the property has passed into the hands of the State.

\footnotetext{
${ }^{3}$ Recall that according to Bolsheviks, all noncommunist trends of socialism were a variety of social democracy and the latter was a moderate wing of fascism.
} 
Gindler (2020) generalized that non-Marxian flavors of socialism, such as Italian Fascists and German National Socialists, utilized collectivization of consciousness and wealth redistribution as the main paths to socialism. They intended to socialize individuals before collectivizing the economy.

Stalin refused to acknowledge that the National Socialist German Workers' Party (Nationalsozialistische Deutsche Arbeiterpartei, NSDAP) was indeed a party of socialist crusaders. He disingenuously stated that German fascism was "wrongly called nationalsocialism - wrongly because the most searching examination will fail to reveal even an atom of socialism in it" (Stalin [1954d] 2008). Entirely on the contrary, Hitler's twenty-five-point program and his future activities had all the "socialist" atoms and one alien bit called Nazism (Office of the United States Chief Counsel for Prosecution of Axis Criminality 1946). It was not a far-left program of Marxism, but it was a social chauvinist program of leftist "reformism." Indeed, Hitler did not explicitly call for an outright expropriation of the means of production, but neither did Social Democrats. The "National Socialist German Workers' Party" was not a right-wing party, neither imagined nor real. It conducted a large-scale socialistic reform according to its leftist platform and identical to the programs of most European leftist parties with just a subtle caveat: Nazis were building socialism exclusively for the super-race of Aryans.

By 1935, Communists had abandoned their policy of social fascism, as their war on social democracy had backfired in a major way. After just three months of acquiring power, Nazis officially outlawed communist and social democratic parties and crushed trade unions. Like Mussolini before him, and Bolsheviks before Mussolini, Hitler eliminated opposition and organized a dictatorship of his party. Communists stopped calling German Social Democrats social fascists, for an obvious reason: there was no more social democracy in Germany. The only "fascists," the only legal party remaining, was the non-Marxian National Socialist German Workers' Party.

Marxists added, crystallized, and inflated-precisely and consistently-one critical attribute in the definition of fascismnationalism and racism. Ultimately, they proclaimed fascism as a proponent of capital and equated it with Nazism. This redefinition was a logical continuation of Lenin's construction of social 
chauvinists as being a) proponents of "revisionism" and thus bourgeoisie elements in the workers' movement and b) nationalists, deniers of the prevalence of international interests above national ones.

The implication of this labeling was tremendous. Henceforth, the main characteristic of fascism became its severe bigotry and connection to the bourgeoisie. Consequently, laypersons did not look carefully at the similarities of the socio-economic totalitarianism of Fascist, Nazi, and communist states. The only thing people saw in Fascist and Nazi states was nationalistic chauvinism. The only thing observers saw in the Soviet Union was the proclaimed friendship of peoples. Subsequently, capitalism, the Right, was associated with nationalism because fascism was linked to capitalism in Marxist propaganda. It was unscientific circular reasoning that had nothing to do with reality. Comintern propaganda broadcasted across the entire civilized world that fascism was the most vicious enemy of all working people; fascism was the power of finance capital itself; fascism was unbridled chauvinism and an initiator of predatory war (Dimitrov 1972).

This bigotry dimension served as a pretext to shift Fascist and Nazi ideology more to the right in Stalinist political science. Instead of being on the right side within the leftist cluster, these doctrines were forcefully and purposely pushed outside the Left group after 1933. Of course, this shift was imaginary and emotional in nature. It was a protest of the orthodox Marxists and Social Democrats disgusted with living and associating with pure evil. It was a dissent of losers who were defeated in the Left's internecine struggle. Also, the Far Left and center left refused to lose their trademark as internationalists. They had to push Fascists and Nazis far from their legitimate position in the political spectrum.

Marxists won in Russia, but non-Marxian currents of socialism took the upper hand in Italy and Germany. Evolutionary socialists were numerous in Great Britain and France; they did not rule singlehandedly, but they shared seats in the parliaments with other factions and had members in the executive branch of the governments. All three dictatorial regimes-Communist Soviet Union, Fascist Italy, and Nazi Germany-eradicated opposite socialist currents in their respective countries and transferred their fight to the world arena. As a result, social democracy was weakened because the most prominent party, the key repository 
of the European socialist thoughts - the German Social Democratic Party - was crushed. Their colleagues elsewhere in Europe seemed to be irresolute and restricted in their struggle by parliamentary rules. Communists formally expelled Fascists and National Socialists from the socialist camp. Therefore, the Bolsheviks naturally took on the role of real socialists, internationalists, who defended the working people of the entire world, using the Comintern as a stronghold of influence.

\section{SPANISH CIVIL WAR}

The interwar period was characterized by a vigorous reshuffling of alliances between different countries and political movements. Such dynamics were rooted in the Versailles treaty, which was not fair to some winners nor to the loser of World War I. Germany was punished with colossal and humiliating sanctions that undermined it economically, financially, and militarily, to an extent that no civilized nation would endure for a long time. France simply wanted to guarantee its economic and military dominance in Europe by weakening Germany to an unprecedented level. The minor allies of the Entente-Italy and Japan-were deceived by the Western powers, as they did not gain the promised treasure of the war. At the same time, neither England nor France gave up their colonial possessions, but they prevented their junior partners from acquiring promised territory. The deep resentment harbored against France and England made itself felt in the foreign affairs of Italy, Germany, and Japan in the interwar period.

In 1934, relations between Nazi Germany and Fascist Italy were turbulent. Mussolini was afraid of a potential German-Austrian union nearby that could threaten Italy's minor territorial gains after World War I. Italy's political and military actions on the frontier with Austria forced Germany to cancel plans for the immediate Anschluss of Austria. In 1935, Italy joined Britain and France in the Stresa Front, which was created as a watchdog entity that was supposed to prevent Germany from violating the post-World War I Versailles treaty and ensure Austrian independence.

In the same year, Italy began its conquest of Abyssinia with the tacit consent of France and England. Germany secretly supported Abyssinia, hoping that Italy would be embroiled in this war for a long time. The Soviet Union, proclaimed internationalists, supplied Italy with oil and petroleum, thus literally and figuratively fueling 
the invasion. To Mussolini's surprise, the League of Nations imposed economic sanctions on Italy that estranged it from the Western powers. Simultaneously, Great Britain undermined the Stresa Front by signing a separate naval agreement with Germany without consulting Italy or France. Therefore, the shortsighted and duplicitous policy of Western governments toward Italy and the expansionist policy of the latter resulted in Italy's drift closer to Germany and other European countries that had lost in World War I.

In 1935, the Soviet Union sought collaboration with social democracy. The Seventh World Congress of Communist International decided to fight Fascists and Nazis with their united force; thus, Comintern adopted a policy of the Popular Front. It was logically understandable, since a one-on-one fight between Communists and Fascists and Nazis resulted in the devastating defeat of the former during the interwar period. Ideologically, Marxist internationalism was overwhelmed by non-Marxist National Socialism and fascism. In Germany and Italy, forced national interclass cooperation had prevailed over the notion of the class struggle. Communists decided to alter course-dialectically - as they tried to explain any developmental changes.

Comintern designated Nazi Germany and imperial Japan as primary enemies of Communists and chief instigators of the war. (Interestingly, Italy was not described in very harsh terms, probably because of the mutually beneficial economic relations between Italy and the Soviet Union at that time.) In turn, in November 1936, Germany and Japan signed the anti-Comintern pact, which was directed against the Soviet Union's interests. Additionally, in 1936, Italy and Germany signed the Axis protocol that designated the Mediterranean as Italy's sphere of influence. Therefore, in just two years, Italy was converted from an enemy into an ally of Nazi Germany.

Meanwhile, the policy of the Popular Front brought forth its first fruits. Socialistic governments backed by the Popular Front were elected in France and Spain in 1936. For Spain, however, the victory was short lived. Spain had been suffering through a time of severe calamities that culminated in a civil war in 1936. The Spanish Civil War was another significant period that disturbed the political spectrum even more. Anarchists, communists, and socialists were united under the Popular Front (also known as the Republicans), which scored a very narrow victory ( 2 percent) in 
the Spanish elections. The opposition was a broad conglomerate of parties, including monarchists, the Confederation of Autonomous Right-Wing Groups (Confederación Española de Derechas Autónomas, CEDA), and Falangists, which called themselves the Nationalist Front. Republicans perceived the struggle as democracy versus fascism and freedom versus tyranny; the rebels thought they were destined to save "Christian civilization" against "red hordes" of anarchists and communists (Beevor 2006).

Tens of thousands of extreme leftists from all over the world gathered in Spain to fight the Nationalists. The former had created several International Brigades which were backed by Comintern and the Soviet Union. Trotskyist volunteers did not join the International Brigades; they created their own paramilitary force, based on the Workers' Party of Marxist Unification (Partido Obrero de Unificación Marxista, POUM).

The Spanish Civil War was a battleground not only for Spaniards but also for the political ambitions of leading European governments. Fascist Italy and Nazi Germany supported the Nationalists. European democracies, as well as the League of Nations, refrained from involvement in the conflict, utilizing useless pacification rhetoric.

Mussolini had a grandiose ambition of reestablishing the Roman Empire in the Mediterranean. When Nationalist Francisco Franco asked for help, Mussolini immediately seized the opportunity to be involved in the conflict, which was occurring in the territory of his would-be empire. Mussolini sought to forestall a Communist takeover in Spain and to weaken the Popular Front government of France. He tried to prevent the potential union of the Popular Front governments of Spain and France, as they could stand together against Italy's imperialistic ambitions in the Mediterranean. Also, Mussolini hoped that the Nationalists' victory would result in an eventual eviction of Great Britain from Gibraltar. Germany tried to solidify its ties with Italy and weaken the relationship between Italy, France, and Great Britain by drawing Italy into the Spanish Civil War (Knight 2003).

Neither Italian Fascists nor Nazi Germany could have allied with the Republicans after purging the center left and Far Left in their corresponding countries. The unpleasantness between the Far Left and social chauvinists was deep and mutual. Thus, both found that it was more natural to collude with the Falange, which had some 
nationalist implications in its program and deeds. Another reason for Fascist and Nazi involvement in the foreign civil war was the necessity to assess new military equipment, techniques, and tactics in preparation for the future armed conflicts. They used Spain as a military testing ground.

The Soviet Union tried to accomplish several goals as well. These objectives were preparation for future wars, revenge against Fascists and Nazis, and elimination of anti-Stalinist Trotskyist groups. The latter purpose was very peculiar. In essence, Stalin unleashed another war within the Spanish Civil War. Moreover, this was done on top of the socialist revolution that anarchosyndicalists managed to superimpose in Spain.

Trotsky intensively criticized the Soviet regime from the left and suggested that the Soviet Union's working class would eventually rise, oust the Soviet bureaucracy, and organize the actual proletarian state. For this cause, Trotsky had created the Fourth International in 1938, where he preached a genuine Marxism and methods of helping the Soviet proletariat smash the Stalinist regime. Trotsky thought that a small example somewhere else in the East or the West would shake up the scared, demoralized, and ensnared Soviet working class (Trotsky 1937). He had high hopes for a revolution in Spain and his POUM loyalists. To counter Trotsky's actions, Stalin sent the Soviet secret agents of the People's Commissariat of Internal Affairs (Народный Комиссариат Внутренних Дел [Narodniy Komissariat Vnutrennikh Del], NKVD) to hunt down POUM fighters. The NKVD eliminated numerous prominent Trotskyists, including the head of the POUM, Andreas Nin, thus undermining in part the Popular Front.

Let us recall that just several years earlier, Communists had undercut European social democracy, paving the way for the Nazis to rise to power. In Spain, Communists, yet again, did not cooperate with the rest of the Left. They shockingly weakened the Left while they were holding their positions in the trenches against the Nationalists. Although not the primary cause, this nevertheless played a subtle role in the Republicans' loss. Regardless of Stalin's true intentions, it was the Nationalists who defeated the Popular Front aided by the Soviets and the Comintern.

Realizing the impending defeat of the Comintern in the proxy war with the fascists and nationalists, the Bolsheviks vigorously sought alliance with the Western powers. The Soviets could not 
reach a collective security agreement with Great Britain and France, who were engaged in appeasement policy. Stalin, thus, decided to seek peace with Germany just a couple of weeks after the Spanish Civil War had ended. The result of the negotiations between Nazi Germany and the Communist Soviet Union was the Nonaggression Pact and secret protocols of August 23, 1939. The two sides became allies, thus postponing their inevitable and final clash.

Immediately, Soviet propaganda with a hostile attitude toward the National Socialist state disappeared. Nazi Germany became a friendly regime, and the labels "Nazi" and "Fascist" disappeared from the pages of Pravda. Germany signed lucrative contracts with the Soviet Union. Hundreds of thousands of railroad cars with strategic raw materials arrived in Germany from the Soviet Union until the German invasion in 1941.

The Spanish Civil War dramatically changed people's perception of political ideologies and factors that influence political spectrum polarization. First, the entire world saw that Fascist Italy and Nazi Germany did not support Republicans-the international left; they openly aided the Spanish rebels. Even though history shows that many unions form out of convenience, the Fascists and Nazis' policy of backing the Nationalists was interpreted quite unequivocally by observers. They concluded that Fascists and Nazis were right-wingers. Second, the extra dimension-nationalism and racism - prevailed in qualifying who was on the right or the left of the political spectrum. This dimension outlasted all other criteria; the rest became irrelevant.

The brown banner of extreme genocidal bigotry was expressly, emotionally, and artificially hung in front of the world's eyes to cloak very leftist, socialist economic transformations in Italy and Germany. This banner was critical to blurring the undisputable similarities between the Communist Soviet Union, Fascist Italy, and Nazi Germany. Thus, fascism and Nazism were driven to the right side of the political spectrum. The Right did not have time to respond adequately, as World War II started just five months after the Spanish Civil War had ended.

\section{WORLD WAR II}

World War II was initiated by the two aggressive leftist regimes of Nazi Germany and the Communist Soviet Union on September 1, 1939. For the first two years of World War II, they were allies. 
They partitioned Eastern Europe as a sphere of influence, quickly annexed corresponding territories, and established totalitarian regimes. Each time, the aggressors congratulated each other on the last victory and even commemorated their success with a joint military parade in Brest. However, their friendship was not sincere but forced by the circumstances. Neither regime gave up their ideas: Nazis intended to expand the Aryan homeland at the expense of Eastern European territories, and Bolsheviks dreamed of a permanent worldwide communist revolution, despite Stalin's thesis about the possibility of building socialism in a single country. The two regimes' clash was inevitable once they acquired a common border after conquering neighboring countries.

On June 22, 1941, Hitler outstripped Stalin and reluctantly (the war on two fronts had led to the defeat of Germany in the First World War), but out of necessity, attacked him first. The Soviet Union assumed the posture of an innocent victim of Nazi aggression. It began to carry out a series of measures to veil its involvement in inciting World War II. Thus, the Soviets invented a Great Patriotic War that started on the day of the German invasion, camouflaging their first two years of mutually beneficial military and economic cooperation with the Nazis.

Retrospectively, the Soviet Union explained away the part of Europe that it had annexed as a preventive measure to protect those nations from the evil of Nazism. Soviets denied the existence of the secret protocols of the Ribbentrop-Molotov Pact, which outlined the partitioning of occupied Europe between the Germans and Soviets, respectively, until Mikhail Gorbachev's time. Communist rulers negated the execution of Polish officers by Soviet punitive troops and shifted the blame onto the Germans' shoulders.

To everyone's delight, the Nazis and their allies lost World War II. The Soviet Union and its Western allies crushed German Nazism, Italian fascism, and Japanese Empire in 1945. The whole world was stunned by the number of hideous, inhumane crimes committed by the Nazis. Mass murder and torture had been performed on a scale unseen before. The Holocaust, as well as the genocide of other ethnicities, was incomprehensible.

As a result, neither the Left nor the Right wanted to have anything in common with Fascists and Nazis. In people's minds Fascists and Nazis had already occupied the right wing of the political spectrum since the Spanish Civil War. As such, those regimes were pushed 
even further to the right and began to occupy the artificial extreme right of the political spectrum. Perception had become reality.

Communists eventually exacted their revenge: fascism and Nazism were destroyed, and social democracy disappeared in all countries that were drawn into the Soviet orbit. The great Winston Churchill could not do much against the progressivist Franklin D. Roosevelt and the Communist Stalin. As a result of the Yalta postwar world partition, millions of Europeans fell under Communist oppression.

It is said that the victors write history. Communists methodically imposed their political views with the ample help of various leftist intellectuals and sympathizers in the West. The people of Europe appreciated the fact that Soviet troops had captured Berlin and destroyed the evil in its lair. They readily forgot the USSR's role in inciting the war and silently agreed upon fixing fascism on the right. Soviets and their adherents in the West did their best to camouflage Stalin's repression and mass murder of his own people. Existential Nazi evil was placed on the far right. No less brutal Communist evil, which covered up its atrocities with the empty words "about world peace," continued to take a left-wing position.

\section{COLD WAR AND PRESENT DAY}

After the Fascists and Nazis were defeated, the world found itself in another confrontation. This time, it was a cold war between the free world, led by the US, and the Communist camp, led by the Soviet Union. This conflict had its "hot" outbreaks in different corners of the world in the form of proxy wars.

During the Cold War, Communists associated fascism with the right wing in their propaganda on a wide scale. It is characteristic that the brainwashing met almost no resistance from the Right. Teachers at high schools and liberal professors in colleges told pupils and students worldwide that fascism is an ultraright-wing ideology characterized by extreme nationalism and racism. This was, in essence, Stalin's political science. This continues today. Moreover, single voices who disagreed were ridiculed in predominantly liberal academic circles, mass media, and social networks.

However, after the collapse of the Soviet Union and the Warsaw bloc, many Communists' dirty secrets were revealed. Thoughtful people realized that communism has as many dangers as fascism, 
if not more. All countries that have practiced communism have caused more death than the Fascist and Nazi states (Courtois, Albert, and Kramer 1999). The oppression of human dignity, torture, and deprivation of elementary human rights continues in the several remaining Communist countries. As for nationalism and racism, Communists have skeletons in their closets as well. Faithful Leninists carried out a policy of coerced russification. They closed national schools, newspapers, magazines, and houses of worship; they repressed Don Cossacks; deported Poles, Ukrainians, Moldovans, and people from the Baltic states; extradited Volga Germans, Crimean Tatars, Chechens, and Ingush; starved to death 4 million Ukrainians during the Holodomor; they were outright anti-Semitic as well. Only Stalin's death saved Soviet Jewry from a genocide that would have matched that of the Nazis. Subsequent Communist leaders continued anti-Semitic policies on a state level, not to mention inciting domestic anti-Semitism. The free capitalist world fought against the bigoted policy of the Soviets. Eventually, Jews were allowed to leave the Soviet Union for good.

The crimes of communism are as inhuman as the crimes of fascism and Nazism. All three regimes built totalitarian states, subordinating the individual will to the collective one. They infringed on private property rights in one way or another. As is well established within the libertarian stripe of political philosophy,

[t]he essential mark of socialism is that one will alone acts. It is immaterial whose will it is. The director may be an anointed king or a dictator, ruling by virtue of his charisma, he may be a Führer or a board of Führers appointed by the vote of the people. The main thing is that the employment of all factors of production is directed by one agency only. One will alone chooses, decides, directs, acts, gives orders. (Mises [1949] 1998, 691-92)

Nevertheless, in modern political science, Fascists and National Socialists are considered the Far Right. The Left is working hard to keep this myth alive. Exposing this would lead Western left-wing intellectuals into a state of acute cognitive dissonance. They would find that leftist ideology continuously breeds existential evil, which is not alien to the large-scale genocide of the dissident population. Thus, they prefer to completely deny the fact that fascism and Nazism were left-wing phenomena.

After the defeat of National Socialism and fascism, social democracy blossomed in Western countries, ironically adopting 
the former regimes' sociopolitical decisions. Aly $(2008,21)$ claims that Germany's postwar government has continued to carry out Hitler's social policy. The author specifically pointed out:

Nazi-era policies paved the way for many postwar reforms, everything from European Union agricultural policy, joint tax returns for couples, and compulsory liability insurance for drivers to state child-support allowances, graduated income tax, and the beginning of environmental conservation. Nazi civil servants drafted the outline for a pension system that anticipated the one adopted in 1957 by the Federal Republic of Germany.

Removing the nationalism of Fascist Italy and Nazi Germany shows that both governments were the progenitors of modern European nanny states. Social democracy utilized the same paths to socialism as the Fascists and Nazis, that is, wealth redistribution and collectivization of consciousness. The only difference is that Fascists used a revolutionary approach, violently altering the state's structure to speed up the socialization of the individual. In contrast, social democracy uses an evolutionary method employing democratic procedures. Every time socialists gain power, they try to impose different measures to increase wealth redistribution, intensify state regulation, and assault private property rights.

Evolutionary socialism eventually became the prevailing trend among the Left. Anarchism and communism are relatively marginal forces. The moderate left often uses them as a paramilitary wing to promote socialist ideas on their behalf using intimidation, protest, and riot. Thus, Antifa bases its violent actions on the myth that fascism and Nazism are right-wing political philosophies closely associated with capitalism. Black Lives Matter uses a narrative of state racism and targeted police brutality against blacks as the moral justification for their frantic protests. An essential myth developed by the Left is the victimization of various segments of the population, while the issue of nationalism and racism continues to play an important ideological role. Modern leftist elites encourage a victim mentality in many strata of the population, convincing them that the only way to improve their lot is to enforce more redistributive policies. The secret aim of these leftist elites is to perpetuate the welfare state as a means of preserving the Left's political and economic power. 


\section{CONCLUSION}

Historically, socialism was represented by different currents that had very complicated relationships with each other. Each trend insisted that their path to a "socialist" paradise was righteous, while all other ideas seemed to betray the interests of the "oppressed" classes. The most radical elements advocated complete and outright socialization of private property and consciousness and proudly occupied the far-left position in the left-wing movement. They have methodically pushed others to the right, thus implying their connection with the bourgeoisie.

The internecine struggle intensified after the formation of nonMarxist, nonconformist currents of socialism in the early twentieth century, which challenged Marxism's vital provisions. The acute ideological confrontation over the issue of internationalism and nationalism on the eve of World War I resulted in an insoluble split between the socialists that led to the dismantling of the Second International. Marxists stigmatized the socialists who supported their countries in the war, called them social chauvinists, and pushed them even further to the right flank.

In the interwar period, Communists expelled Fascists and Nazis from the ranks of socialist movements in their propaganda, as they did not expropriate the means of production according to the Marxist recipe and Bolshevik practice. Also, the issue of nationalism became a bifurcation point in political philosophies promoted by the Comintern. The ideological contradictions of socialist rivals spilled over into the world arena in the form of the proxy wars. During the Spanish Civil War (1936-39), the entire world observed that socialist internationalists defended the Spanish Republicans, whereas Fascists and Nazis supported the Nationalists, mostly comprising right-wing parties. At this point in time, fascism and Nazism became firmly associated with the Right in the global public's perception.

In the course of World War II, the Allied forces crushed fascism and Nazism and revealed the hideous crimes committed by nationalists against humanity. Neither the Right nor the Left wanted to have anything in common with Fascists and Nazis; the latter doctrines were forcefully shifted to the ultraright. As a winner in World War II, the Soviet Union took the opportunity to rewrite history and promoted Marxism-Leninism as the only genuine kind of socialism. 
During the Cold War, Soviet propaganda successfully brainwashed many Western intellectuals with Stalinist political science. The artificial placement of fascism and Nazism on the right and the employment of nationalism as a factor that governs the political spectrum's polarization found their way into school and university textbooks.

The truth is that fascism and National Socialism have always been non-Marxian flavors of socialism and should occupy the right wing of the Left on the political spectrum. Their placement on the extreme right wing is artificial, unwarranted, and was done as a purely propagandistic measure during the acute internecine struggle among socialist currents. Nationalism is not a determining factor in the polarization of the political spectrum. Indeed, xenophobic ideas can characterize both left- and right-wing ideology. However, the dramatic history of the twentieth century shows that nationalism, overt and covert, is instead inherent to the Left.

\section{REFERENCES}

Aly, Götz. 2008. Hitler's Beneficiaries. New York: Holt Paperbacks.

Bakunin, Mikhail. 1971. Statism and Anarchy. Translated and edited by Sam Dolgoff. Marxists Internet Archive. https://www.marxists.org/ reference/archive/bakunin/works/1873/statism-anarchy.htm.

Beevor, Antony. 2006. The Battle for Spain: The Spanish Civil War, 1936-1939. London: Weidenfeld and Nicolson.

Bernstein, Eduard. 1907. Evolutionary Socialism. St. Petersburg: Independent Labour Party, Red and Black Publishers. Kindle.

Courtois, Stéphane, G. Peter Albert, and Mark Kramer. 1999. The Black Book of Communism: Crimes, Terror, Repression. Cambridge, Mass.: Harvard University Press.

Draper, Theodore. 1969. "The Ghost of Social-Fascism." Commentary, February 1969. https://www.commentarymagazine.com/articles/ theodore-draper/the-ghost-of-social-fascism/.

Dimitrov, Georgi. 1972. "The Fascist Offensive and the Tasks of the Communist International in the Struggle of the Working Class against Fascism." In Georgi Dimitrov, Selected Works. Sofia, Bulgaria: Sofia Press. Marxists Internet Archive. https://www.marxists.org/ reference/archive/dimitrov/works/1935/08_02.htm.

Engels, Friedrich. 1969. "The Principles of Communism." In Karl Marx and Frederick Engels, Selected Works, vol. 1, 81-97. Moscow: Progress Publishers.

Florinsky, Michael T. 1938. Fascism and National Socialism. New York: Macmillan. 
Gindler, Allen. 2019. "What Did Marx and Engels Think of Other Races?" American Thinker, Apr. 22, 2019. https://www.americanthinker.com/ articles/2019/04/what_did_marx_and_engels_think_of_minorities.html.

_ . 2020. "The Theory of the Political Spectrum." Journal of Libertarian Studies 24, no. 2: 240-71. https://jls.scholasticahq.com/article/ 24375-the-theory-of-the-political-spectrum.

Knight, Patricia. 2003. Mussolini and Fascism: Questions and Analysis in History. New York: Routledge.

Lenin, V. I. 1973a. "Marxism and Revisionism." In Lenin's Collected Works, vol. 15, 29-39. Moscow: Progress Publishers.

_ 1974b. "The Position and Tasks of the Socialist International." In Lenin's Collected Works, vol. 21, 35-41. Moscow: Progress Publisher.

_ 1974c. "The Tasks of the Proletariat in Our Revolution." In Lenin's Collected Works, vol. 24, 93-106. Moscow: Progress Publishers.

Marx, Karl. 1969. Manifesto of the Communist Party. In Karl Marx and Frederick Engels, Selected Works, vol. 1, 98-137. Moscow: Progress Publishers.

Mises, Ludwig von. (1949) 1998. Human Action: A Treatise on Economics. scholar's ed. Auburn, Ala.: Ludwig von Mises Institute.

— 1951. Socialism: An Economic and Sociological Analysis. Translated by J. Kahane. New Haven, Conn.: Yale University Press.

Mussolini, Benito. 1933. The Political and Social Doctrine of Fascism. Translated by Jane Soames. London: Hogarth Press.

Office of the United States Chief Counsel for Prosecution of Axis Criminality. 1946. "1708-PS: National Socialistic Yearbook 1941." In Nazi Conspiracy and Aggression, vol. 4. Washington, D.C.: United States Government Printing Office. The Avalon Project. https://avalon.law. yale.edu/imt/1708-ps.asp.

Pitigliani, Fausto. 1933. The Italian Corporative State. London: P. S. King and Son.

Rothbard, Murray N. 2009. Man, Economy, and State, with Power and Market. 2d scholar's ed. Auburn, Ala.: Ludwig von Mises Institute.

Sorel, Georges. (1908) 2014. Reflections on Violence. Reprint, London: George Allen and Unwin. Kindle.

Stalin, J. V. (1954a) 2008. “Concerning the International Situation," Sept. 20, 1924. In Works, vol. 6, January-November, 1924, 293-314, Moscow: Foreign Languages Publishing House. Marxists Internet Archive. https://www. marxists.org/reference/archive/stalin/works/1924/09/20.htm.

- (1954b) 2008. "Political Report of the Central Committee," Dec. 18, 1925, in "The Fourteenth Congress of the C.P.S.U. (B.)," December 18, 1925. In Works, vol. 7, 1925. Moscow: Foreign Languages Publishing House.MarxistsInternetArchive.https://www.marxists.org/reference/ archive/stalin/works/1925/12/18.htm. 
(1954c) 2009. "Political Report of the Central Committee," Dec. 3, 1927, in "The Fifteenth Congress of the C.P.S.U. (B.)," Dec. 2-19, 1927." In Works, vol. 10, August-September, 1927. Moscow: Foreign Languages Publishing House. Marxists Internet Archive. https://www.marxists. org/reference/archive/stalin/works/1927/12/02.htm.

. (1954d) 2008. "Report to the Seventeenth Party Congress on the Work of the Central Committee of the C.P.S.U. (B.)," Jan. 26, 1934. In Works, vol. 13, 1930-January 1934. Moscow: Foreign Languages Publishing House. Marxists Internet Archive. https://www.marxists. org/reference/archive/stalin/works/1934/01/26.htm.

. 1954e. "Results of the July Plenum of C.C., C.P.S.U. (B.)," July 13, 1928. In Works, vol. 11. Moscow: Foreign Languages Publishing House. Marxists Internet Archive.https://www.marxists.org/ reference/archive/stalin/works/1928/07_13.htm.

. (1955) 2000. "Political Report of the C. C. to the Sixteenth Congress of the C.P.S.U. (B.)," June 27, 1930. In Works, vol. 12, 242-385. Moscow: Foreign Languages Publishing House. Marxists Internet Archive. https://www.marxists.org/reference/archive/stalin/works/1930/ aug/27.htm.

. (1978) 2008. "Interview between J. Stalin and Roy Howard," Mar. 1, 1936. In Works, vol. 14. London: Red Star Press. Marxists Internet Archive. https://www.marxists.org/reference/archive/stalin/ works/1936/03/01.htm.

Sweezy, Paul M., ed. 1949. "Karl Marx and Close of His System" by Eugen von Böhm-Bawerk and "Böhm-Bawerk's Criticism of Marx" by Rudolf Hilferding. New York: Augustus M. Kelley.

Trotsky, Leon. 1937. The Revolution Betrayed: What Is the Soviet Union and Where Is It Going? Detroit, Mich.: Labor Publication. Kindle.

. (1973) 2003. "Invitation to the First World Congress," Jan. 24, 1919. In The First Five Years of the Communist International, vol. 1, translated by John G. Wright and R. Chappell. London: New Park. Marxists Internet Archive. https://www.marxists.org/archive/trotsky/1924/ ffyci-1/app04.htm.

. (1974) 2003. "Political Perspectives," late 1922? The First Five Years of the Communist International, vol. 2, translated by John G. Wright. London: New Park. Marxists Internet Archive. https://www.marxists. org/archive/trotsky/1924/ffyci-2/index.htm. 